\title{
Developing Instructional Design Model of Speaking Skill for First Year Undergraduate Students
}

\author{
Harpain \\ Faculty of Teacher Training and Education, Universitas Bandar Lampung, Indonesia \\ Dameria Magdalena Sidabalok \\ Faculty of Teacher Training and Education, Universitas Bandar Lampung, Indonesia \\ Margaretha Audrey Stefani Cahyani \\ Faculty of Teacher Training and Education, Universitas Bandar Lampung, Indonesia \\ Yulfriwini \\ Universitas Bandar Lampung, Indonesia
}

\begin{abstract}
This study was conducted to search for Contextual Teaching and Learning model suitable for developing English speaking skill for first-year students of undergraduate study of Teacher Training and Education Faculty of Universitas Bandar Lampung. In teaching speaking, especially for Second Language and Foreign Language Learners, it was assumed that learning speaking by using tailored instructional design model could accelerate student speaking development. The result of this study should construct a model which is suitable for developing English speaking skill in the first year of undergraduate study.
\end{abstract}

Index Terms - instructional design, contextual learning, speaking skill, undergraduate level

\section{INTRODUCTION}

Talking about English nowadays, people will focus on speaking skill. It happens because communication is everything in this era. English as a global language means that English influences the daily life of many people. Students are forced to learn English because of society demand. An employer wants a worker who has good communication skill. Byrne (2010) as cited by Bruner, Sinwongsuwat, and Radic-Bojanic (2015) provides an example on the fact that CEO and major companies in Asia demand their workers to have good English proficiency for international investment. This is why speaking becomes one of the most important skills to master.

In Indonesia learning to speak English properly is difficult. The result of learning English for at least six years from junior to senior high school has not been optimal for mastering the four basic skills of English language. This happens because most teachers in Indonesia still use mother language more than the English language in a teaching-learning situation even though they are actually teaching English. Most of the students who are in an undergraduate study now learned their subjects using the old curriculum of 2006 where learning is not integrated between subjects. The subjects were even categorized based on whether each subject was aimed to form student personality, skill or knowledge. This made student unable to relate the lessons to other related topics or subjects since they were used to the complete separation of them. It made the students unable to apply their knowledge in their daily life.

Consequently, when the students enter university, lecturers and educators in the university are forced to review and reteach the students' years of knowledge that they should have had learned before. Language is a skill and must be practiced and used in a real-life situation. The actualization of university students as the next generation is recognized from speaking ability (Darmuki, 2017). Unfortunately, students tend to use English exclusively inside classroom. Due to their limited use of English, they still have many difficulties in using English in their daily life. Since the students did not use English to speak regularly enough to be fluent in speaking, the lecturers are forced to think of a way to design the lesson as close as possible to the situation that happens in real life. This is where contextual learning comes forth.

Contextual learning is an integrated learning in which student learns a topic from different activities that are connected to real life situation (Schunk, 2012). For example, when a student learn about directions the student might learn new vocabularies about them, listen and watch videos about them, draw direction maps, practice asking and giving directions in a role play, etc. The activities are designed for the student to become an active participant in their learning experience. In order for the student to improve their speaking skill and use it actively, contextual learning is chosen as it provides a link between topics of discussion and a real life application and it also retains the experience in long-term memory for future use in life (Surdin, 2018). Still using the same topic about directions, if the student travels 
abroad either for work, vacation or further study, they could use their knowledge to ask directions to the locals (in case they are traveling to remote areas without internet, Google maps, or low cellphone battery). They will recall their previous experience they had in a role play. They can also go to a tourism site where there are many foreigners and try to help them when they ask how to go to a certain place. The situation above illustrates the importance of learning with constructivism.

\section{LITERATURE REVIEW AND HYPOTHESIS DEVELOPMENT}

\section{A. The Concept of Speaking Skill}

English is an international language used by people all over the world. The communication which occurs among people is often direct or oral speech. (Asakereh and Dehghannezhad, 2015). If asked which skill is the most important one, people will most likely answer speaking. This is because many people gauge their mastery of language from their speaking ability. (Richard, 2008).

In the present time where job is open to everyone all over the world, a good English skill is a must. The ability to use English actively opens better chances and opportunities. It was explained by Baker and Westrup (2003) as cited by Baniabdelrahman (2013) that students' speaking ability will increase their chance of getting a job offer and gaining promotions. It is proven from Byrne's (2010) example as cited by Bruner, Siwongsuwat, and Radic-Bonjalic (2015) that $\mathrm{CEO}$ of Asian major companies made English proficiency compulsory for their workers as it is an international investment.

However, speaking skill is not something that can be learned easily. Many experts agree that it is is a very difficult skill to master. One of the experts, Shumin (2002), as cited by Oradee (2012) states that learning to speak a new language is very difficult. Speaking skill is very complex and there are many things that need to be taken into consideration in learning it.

Florez (1999) as cited by Sakale (2012) defines speaking as a formulation of thoughts to form correct meaning based on a topic or situation, participants, environment and the purpose of speech. The definition shows the complexity of speaking since there are many factors that need to be accounted. The definition shows that in speaking, people are processing things internally by constructing a format inside their mind. Then, they will connect it with meaning based on context and the goal of speaking. After that, they will absorb information from the environment and their participant reaction before using their speech.

Another definition of speaking which is similar but even more complex comes from Scriver (2005) as cited by Asakereh and Dehghannezhad (2015) who says that mastering speaking a person needs to have enough knowledge in vocabulary, grammar, culture of the target language, genre, speech acts (noun, pronoun, adverb, adjective, etc.), register (speaking choice of channel influenced by field, tenor and mode), discourse (knowing how to organize speech), and phonology (how to sound words). Contextual learning that adds new information to their prior knowledge, learning and practicing the knowledge before applying it in a real life situation (Hudson and Whisler, 2008) is in line with the steps in speaking. Therefore, the application of this learning might be worth trying in developing speaking skill.

\section{B. Contextual Learning}

There are many definitions of contextual learning (Satriani, Emilia, and Gunawan, 2012) which make inconsistencies on the meaning of Constructivism (Schunk, 2012). Hyslop-Margison and Strobel (2008) and Simpson (2002) as cited by Schunk (2012) said that constructivism is not a theory but an epistemology or the way and process of learning. Satriani, Emilia, and Gunawan (2012) claimed that autonomy learner gained motivation from contextual learning. Students become more active in lessons and they are able to connect better what they learned with their life. This implies that student gains more learning autonomy in contextual learning.

Surdin (2018) has a similar opinion with Satriani, Emilia, and Gunawan (2012). He said students construct their knowledge on their mind by using the information they got academically. They will relate that knowledge with what happens in their daily life. In order to do this, Surdin (2018) emphasizes the importance of storing information received in brain long-term memory. Khaefiatunnisa (2015) supported his view as she stated constructivism as “...meaningful learning which can help students put the material they have learned in long-term memory."

There are many strategies used in constructivism; among them are cooperative learning and inquiry. Cooperative learning is one of the most common strategies used in classes that have abundance of materials and many students in a class. Classes that require many practices like speaking and working in small groups will allow students' equal opportunity in speaking. Satriani, Emilia, and Gunawan (2012) stated that students are not able to gain much when they learn by themselves. This notion is supported by Khaefiatunnisa (2015) arguing that students learn better in groups since they could exchange pieces of information and ideas with other members to gain more and better understanding of the lesson.

Meanwhile, Khaefiatunnisa (2015) stated inquiry is one way of the students to derive knowledge from their own experience and enhance their mind for original ideas and thinking critically. Schunk (2012) defines inquiry as a learning that encourages students to make and solve a problem or a situation. The students then apply the knowledge derived from the experiences in a new situation. This as previously stated, proves that contextual learning is suitable to be used 
in developing speaking skill which half of the process (forming sentences, connecting them with meaning based on their knowledge of topic discussed and situation happening around them) is happening inside peoples' mind.

\section{Instructional Design}

Instruction is normally defined as a set of events embedded in purposeful activities that facilitate learning (Gagne et.al., 2004). This made people assume that instruction came from outside influences. In reality, there is an internal mental process in order to process knowledge gained from instruction. Therefore, in a wider scope, instructions are a set of activities used by the teacher in order to engage students. (Gagne et.al., 2004).This made an instructional design more effective when designed with activity such as cooperative learning, reflective learning (giving and receiving feedbacks), problem-solving and critical thinking (Gagne et al., 2004).

Gagne et.al. (2004) stated there was no a single best model of instructional design because designers tailored instructional design based on what the designers believed to be true. They designed the models based on their principles and theories which affect the students' learning process. This is supported by the University of Michigan in 2003 which listed Penn State University four parts of Instructional Design definition. In the Instructional Design as a discipline, it is said that Instructional Design is the knowledge about research and theories on the process of instructional strategies (Brown and Green, 2016). This is one of the reasons to design instruction personally despite the time and cost consumed.

Below are popular Instructional Design models which are obligatory to be known as a guide for instructional designers through ADDIE process (Analyze, Design, Develop, Implement and Evaluate) (Brown and Green, 2016). Therefore, ADDIE is also used as a prescriptive model on instructional design. Molenda (2003) as cited by Brown and Green (2016) suggested on the actual use of ADDIE. ADDIE is actually used to describe the process of making instructional design model, not a model of instructional design. However, Brown and Green (2016) stated ADDIE could be used to compare or contrast one instructional model with another.

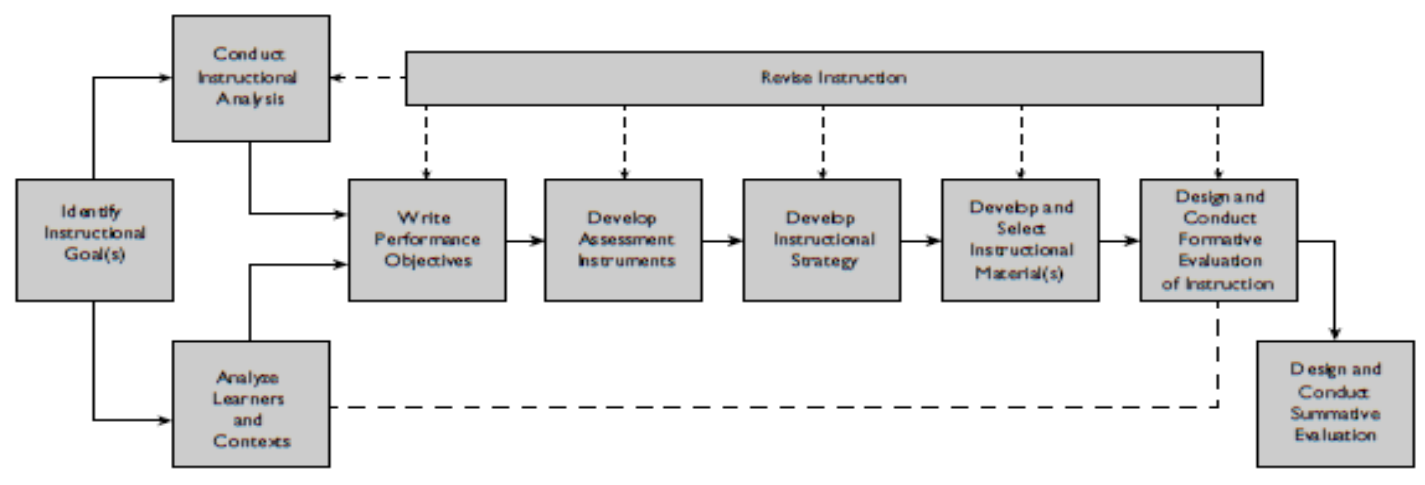

Source: Brown and Green (2016)

Figure 2.1 Dick and Carey's Instructional Design Model

The first model is Dick and Carey's Instructional Design Model. By designing this model, Dick and Carey tried to deviate from the classic classroom instruction. In their time, teaching-learning process put a heavy burden in students. The model they made changed the system into a learning that chose the content based on components of the context.

The second model needs to be paid attention to is Kemp, Morrison and Ross's Instructional Design. Different from Dick and Carey's, Kemp, Morrison and Ross's model is not designed in sequence. It is designed with oval shape without arrows to show that each step could happen at any order or even simultaneously. This model offers more flexibility in teaching-learning process. However, the instructional model in this study will use ADDIE model as a guideline because it is the base of many successful instructional models. 


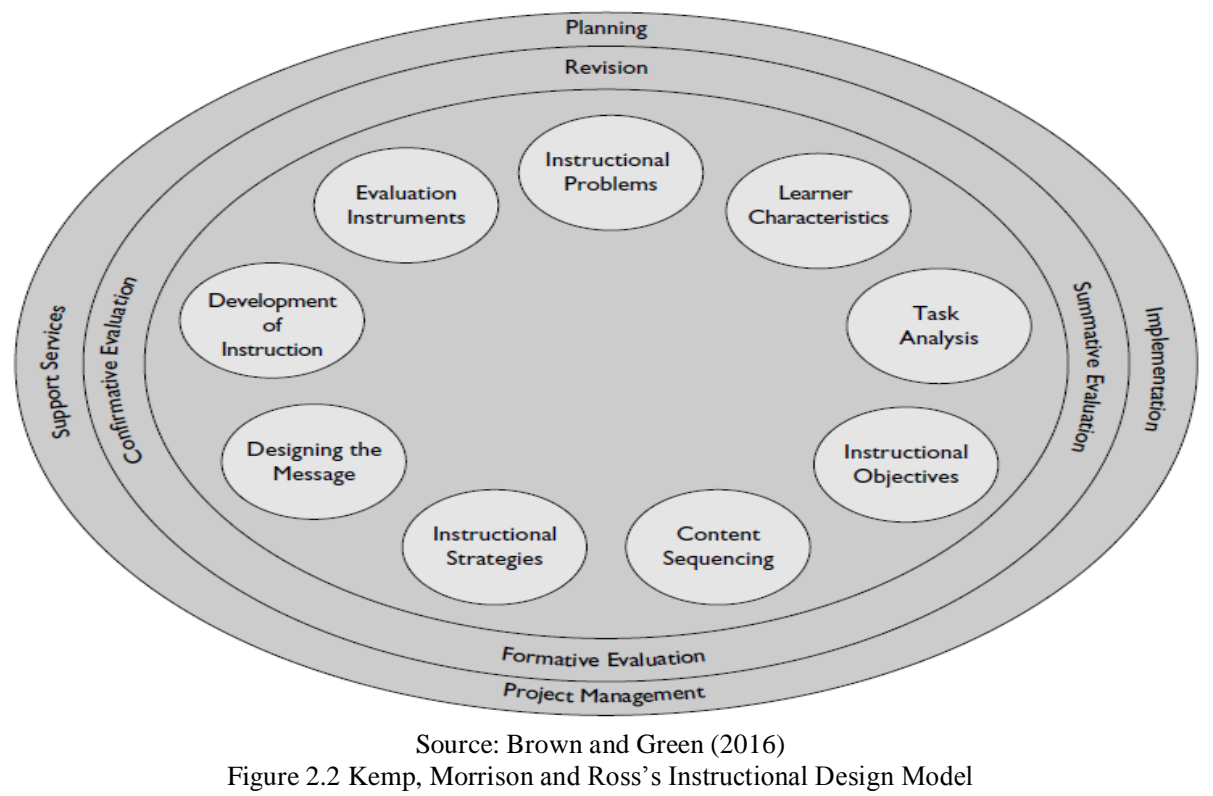

\section{Assessing Speaking}

Due to the various criteria to be considered in speaking, it is not easy to assess it. Many teachers adopt or adapt rubrics in order to make assessment easier. Rubric also helps the teacher make sure they are giving the fairest assessment possible to their students. There are two kinds of rubrics used for assessment. They are holistic rubric and analytical rubric. The holistic rubric is evaluating or scoring overall components of communicative competencies together (Latifa et.al., 2015). In contrast with a holistic rubric which only listed criteria that teacher is going to assess, analytical rubric needs a teacher to: list criteria, group the criteria, and score each criterion before getting the final score (Wiseman, 2012; Latifa et.al., 2015). This kind of scoring, while time consuming (Wiseman, 2012), will give more insights of students' capabilities.

This study needs a more detailed assessment without prolonged time consumptions of analytical rubric. Therefore, Practical Rating Rubric of Speaking Test or in short, P2RST developed by Latifa et.al. (2015) was chosen for this study. This rubric was made because Latifa et.al. (2015) saw the need to make a rubric which is non-time consuming and practical. They combined the nature of holistic rubric which is short and practical with analytical scoring that is more detailed and developed them into P2RST. Below is the detail of P2RST rubric by Latifa et. al. (2015). 
TABLE 2.1

THE LAST REVISION OF P2RST RUBRIC

\begin{tabular}{|c|c|}
\hline Scale & Descriptors \\
\hline 0 & $\begin{array}{l}\text { The speaker is not able to use the rule of (vocabulary competence, syntactic competence, pronunciation, } \\
\text { discourse competence, strategic competence) on his or her utterances at all. }\end{array}$ \\
\hline 1 & $\begin{array}{l}\text { The speaker is able to perform (vocabulary competence, syntactic competence, pronunciation, discourse } \\
\text { competence, strategic competence), but } \\
\text { The speaker still makes many (approximately } 57 \% \text { to } 75 \% \text { ) ungrammatical production. } \\
\text { The speaker only produced the related vocabulary (approximately } 25 \% \text { to } 49 \% \text { ). } \\
\text { The speaker still makes mispronunciation approximately } 66-86 \% \text {. } \\
\text { Speaker disconnected discourse (approximately } 67 \text { to } 83.3 \% \text { disconnected meaning) and hesitation in an } \\
\text { utterance. }\end{array}$ \\
\hline 2 & $\begin{array}{l}\text { The speaker is able to perform (vocabulary competence, syntactic competence, pronunciation, discourse } \\
\text { competence, strategic competence) even he or she still makes some ungrammatical production/unrelated } \\
\text { vocabulary/mispronunciation/ disconnected discourse/ hesitation in an utterance. } \\
\text { Even, he or she still makes some lacks of formality (approximately } 50 \% \text { to } 60 \% \text {. } \\
\text { The speaker only produces } 38 \% \text { to } 50 \% \text { of words and still employs a number of times to recall the words. } \\
\text { The speaker still makes some mispronunciation (approximately } 50 \% \text { to } 62 \% \text { ). } \\
\text { The speaker still produces some unconnected utterances (approximately } 50 \% \text { to } 66 \% \text { ) } \\
\text { The speaker still has some problems to communicate his/her meaning (approximately } 50 \% \text { ). }\end{array}$ \\
\hline 3 & $\begin{array}{l}\text { This level describes that the speaker is able to perform (vocabulary competence, syntactic competence, } \\
\text { pronunciation, discourse competence, strategic competence) in (he or she still makes few ungrammatical } \\
\text { productions/unrelated vocabulary/mispronunciation/disconnected discourse/hesitation in an utterance. } \\
\text { The speaker still makes few lacks of formality (approximately 10-30\%) } \\
\text { The speaker is able to produce approximately 67-90\% of related words but still employs a few times to recall } \\
\text { the words. } \\
\text { The speaker still makes few mispronunciations (approximately 10-33\%). } \\
\text { The speaker still makes few unconnected meanings in communication (approximately } 33 \% \text { ). } \\
\text { The speaker still has a problem to communicate his/her meaning (approximately } 16.7 \% \text { ). }\end{array}$ \\
\hline 4 & $\begin{array}{l}\text { This level describes that the speaker is able to perform (vocabulary c ompetence; syntactic competence, } \\
\text { pronunciation, discourse competence, strategic competence) with no mistakes. } \\
\text { Seems no mistakes in grammar } \\
\text { Speaks very fluently and seems there is no difficulty to produce words. } \\
\text { Utter the words, phrases, sentences close to native' pronunciation } \\
\text { The speaker has fluently uttered the language which seems there is no problem in communication. }\end{array}$ \\
\hline
\end{tabular}

There are three phases in P2RST rubric as illustrated in the figure below.

PHASE 1

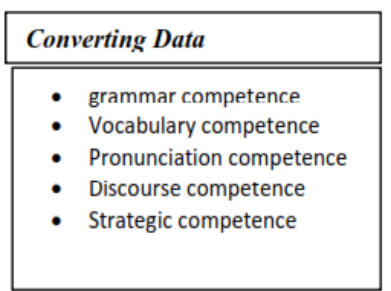

PHASE II

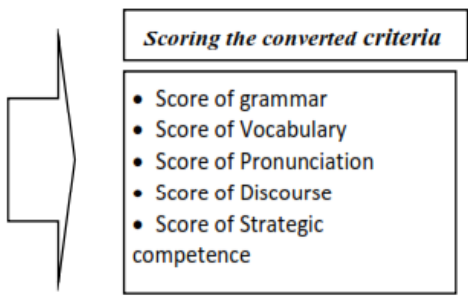

Source: Latifa et.al. (2015)
PHASE III

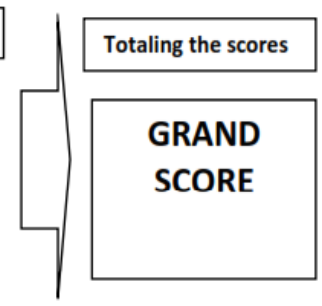

Figure 2.3 P2RST Scoring Mechanism

P2RST descriptors will be used to convert data and match it with the scale to give a score for each criterion. The score of each criterion will be totaled to get the grand score. Latifa et.al. (2015) separate the descriptors and the scoring phases of P2RST. The researcher will adapt the descriptors of P2RST with the criteria for speaking skill and combine them into one. An adjustment is made to ensure the assessment is appropriate to use for analyzing participant level of English. The adjustment is also intended to make the rubric easier to use. Below is the result of the adaptation; 
TABLE 2.2

ADAPTATION OF P2RST RUBRIC

\begin{tabular}{|c|c|c|c|}
\hline Scale & Criteria & Descriptors & $\begin{array}{l}\text { Highest } \\
\text { Score }\end{array}$ \\
\hline 1 & $\begin{array}{l}\text { Content Development } \\
\text { Pronunciation } \\
\text { Vocabulary } \\
\text { Coherency } \\
\text { Performance }\end{array}$ & $\begin{array}{l}\text { Speakers are able to speak approximately } 10-34 \% \text { of the content. } \\
\text { Speaker mispronounces approximately } 70 \% \text { of the time. } \\
\text { Speaker produces approximately } 10-34 \% \text { related vocabulary. } \\
\text { Speakers are able to make connected utterances approximately } 10-34 \% \text {. } \\
\text { Speaker almost always hesitates, pauses and recalls words. }\end{array}$ & $\begin{array}{l}6 \\
3 \\
3 \\
6 \\
6 \\
6\end{array}$ \\
\hline 2 & $\begin{array}{l}\text { Content Development } \\
\text { Pronunciation } \\
\text { Vocabulary } \\
\text { Coherency } \\
\text { Performance }\end{array}$ & $\begin{array}{l}\text { Speakers are able to speak approximately } 35-60 \% \text { of the content. } \\
\text { Speaker mispronounces approximately } 50 \% \text { of the time. } \\
\text { Speaker produces approximately } 35-60 \% \text { related vocabulary. } \\
\text { Speakers are able to make connected utterances approximately } 35-60 \% \text {. } \\
\text { Speaker still hesitates, pauses and recalls words. }\end{array}$ & $\begin{array}{l}12 \\
6 \\
6 \\
12 \\
12 \\
\end{array}$ \\
\hline 3 & $\begin{array}{l}\text { Content Development } \\
\text { Pronunciation } \\
\text { Vocabulary } \\
\text { Coherency } \\
\text { Performance }\end{array}$ & $\begin{array}{l}\text { Speakers are able to speak approximately } 61-80 \% \text { of the content. } \\
\text { Speaker mispronounces approximately } 30 \% \text { of the time. } \\
\text { Speaker produces approximately } 61-80 \% \text { related vocabulary. } \\
\text { Speakers are able to make connected utterances approximately } 61-80 \% \text {. } \\
\text { Speaker makes few hesitations, pauses and recalls words. }\end{array}$ & $\begin{array}{c}16 \\
8 \\
8 \\
16 \\
16 \\
\end{array}$ \\
\hline 4 & $\begin{array}{l}\text { Content Development } \\
\text { Pronunciation } \\
\text { Vocabulary } \\
\text { Coherency } \\
\text { Performance }\end{array}$ & $\begin{array}{l}\text { Speakers are able to speak approximately } 81-100 \% \text { of the content. } \\
\text { Speaker mispronounces approximately } 10 \% \text { of the time. } \\
\text { Speaker produces approximately } 81-100 \% \text { related vocabulary. } \\
\text { Speakers are able to make connected utterances approximately } 81-100 \% \text {. } \\
\text { Speaker seems to not hesitate, pause and recall words. }\end{array}$ & $\begin{array}{l}20 \\
10 \\
10 \\
20 \\
20 \\
\end{array}$ \\
\hline
\end{tabular}

\section{RESEARCH METHODS}

The study is a qualitative research using ADDIE model to design the instruction. The participants of this research were semester 1 students of Teacher Training and Education Faculty of Universitas Bandar Lampung majoring in English Education. There were 53 students in the semester. They had Speaking I class once a week for 100 minutes. They did not really use English outside the classroom. This study was expected to help students develop their speaking skill. This model will hopefully engage the student in teaching-learning process, encourage them to practice, and use English outside the classroom.

The data of this research were gathered through reviewing theories, student speaking skill analysis, and observation. The analysis test will be scored using an adaptation of P2RST Rubric and counted using the Statistical Package for the Social Sciences (SPSS).

\section{DisCUSSIONS AND ANALYSIS OF RESUlts}

\section{A. Instructional Design for Speaking Skill}

By following ADDIE steps for Instructional Design and theories of Contextual Learning, a possible Instructional Design Model for speaking skill is presented below. 


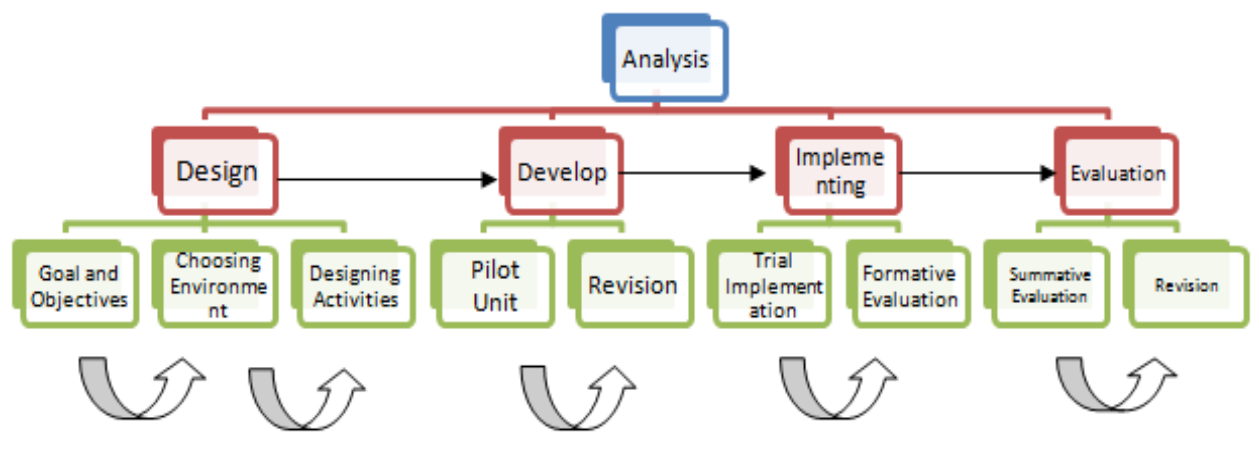

Figure 4.1 Instructional Design of Speaking Skill

In ADDIE, the steps are in sequence as illustrated in the figure below;

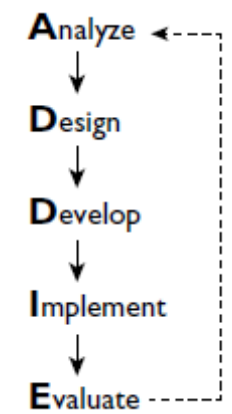

Figure 4.2 The ADDIE Model of Instructional Design (Brown and Green (2016)

In this model, every step from the design to evaluation should be based on the result of the analysis. After getting the result of the analysis, the next step is designing the teaching-learning process. There are three steps to be done in sequence; Goal and objectives (what student needs to be able to do after the whole teaching-learning process), choosing environment (in this step the teacher needs to choose what they would like to have; strict classroom learning, embedded in online learning, place-based learning, etc.) and designing activities (based on the goals and objectives formulated and environment chosen for the teaching and learning process).

After finishing the design, it should be tested to see whether the design is suitable for the target students. There needs to be a separate initial unit which needs to be tested to the student. The result of the unit will be analyzed before being revised according to the student level. When revising the design, previous steps and initial analysis results should be referred to for revision. The other alternative is to make an observation sheet when the pilot unit is commencing and seek experts from inside or outside to score the design. They will be able to give feedback on whether the initial design fits with the design objectives. They will also be able to observe and comment on students' teaching-learning process throughout the pilot unit.

The fourth step is implementing the developed design to a limited number of the students for a longer period of time. The result from the pilot unit might be promising but the design might not be suitable for a longer length of time. Throughout the teaching-learning process, both the design and the student speaking assessment will be revised to help the student gain an optimum result in the study. Therefore, applying the design for a semester in one academic year is recommended. This will help gain a wider scope of result in the design, student reception on it and their speaking development.

Lastly, based on the implementation, there is a major evaluation in the form of summative evaluation. Based on the evaluation, there will be a revision for each step of the instructional design. If the final result cannot reach the goals and objectives of the design, there will be a major revision for each step of the design or even a complete do-over before a discussion on another implementation. If the majority of students meet the goals and objectives of the design, there might be some minor revision before the design is formally launched on a larger scale.

\section{B. Analysis of Student Speaking Skill}

To know the student speaking skill and level, participants received a test to measure their speaking skill. 
TABLE 4.1

LEARNER ANALYSIS SCORES

\begin{tabular}{|c|c|c|c|c|c|}
\hline No & 1. Class A & 2. Class B & No & 3. Class A & 4. Class B \\
\hline 1 & 67 & 65 & 14 & 72 & 58 \\
\hline 2 & 66 & 59 & 15 & 57 & 61 \\
\hline 3 & 65 & 72 & 16 & 70 & 59 \\
\hline 4 & 68 & 46 & 17 & 51 & 60 \\
\hline 5 & 58 & 60 & 18 & 55 & 65 \\
\hline 6 & 73 & 64 & 19 & 48 & 63 \\
\hline 7 & 65 & 63 & 20 & 74 & 60 \\
\hline 8 & 61 & 61 & 21 & 53 & 55 \\
\hline 9 & 48 & 52 & 22 & 61 & 63 \\
\hline 10 & 46 & 62 & 23 & 57 & 58 \\
\hline 11 & 68 & 52 & 24 & 54 & 66 \\
\hline 12 & 49 & 65 & 25 & 59 & 65 \\
\hline \multirow[t]{2}{*}{13} & \multirow[t]{2}{*}{63} & \multirow[t]{2}{*}{66} & 26 & 63 & 55 \\
\hline & & & 27 & 71 & \\
\hline
\end{tabular}

At glance, Class A students had a large gap of skill between students. Some students perform extremely well while others perform poorly. Class B did not have big gaps between students except for one student who scored high on the test. The Pre-Test result was calculated using SPSS independent t-test. There are two hypotheses in the research; the test shows there is significant difference between the two groups (Hi) and there is no significant difference between the groups in their speaking ability (Ho).

TABLE 4.2

STUDENT SPEAKING ANALYSIS RESULT

Group Statistics

\begin{tabular}{|c|c|c|c|c|c|}
\hline & Kelompok & N & Mean & Std. Deviation & Std. Error Mean \\
\hline \multirow{2}{*}{ Nilai } & 1 & 27 & 60.81 & 8.353 & 1.608 \\
& 2 & 26 & 60.58 & 5.442 & 1.067 \\
\hline
\end{tabular}

Independent Samples Test

\begin{tabular}{|c|c|c|c|c|c|c|c|c|c|c|}
\hline & & \multicolumn{2}{|c|}{$\begin{array}{c}\text { Levene's Test for } \\
\text { Equality of } \\
\text { Variances }\end{array}$} & \multicolumn{7}{|c|}{ t-test for Equality of Means } \\
\hline & & $\mathrm{F}$ & Sig. & $\overline{\mathrm{T}}$ & $\overline{\text { Df }}$ & $\begin{array}{l}\text { Sig. (2- } \\
\text { tailed) }\end{array}$ & $\begin{array}{c}\text { Mean } \\
\text { Difference }\end{array}$ & $\begin{array}{l}\text { Std. Error } \\
\text { Difference }\end{array}$ & Lower & Upper \\
\hline Nilai & $\begin{array}{l}\text { Equal } \\
\text { variances not } \\
\text { assumed }\end{array}$ & & & .123 & 44.899 & .902 & .238 & 1.930 & -3.649 & 4.124 \\
\hline
\end{tabular}

Based on the calculation, the result showed that both classes had a small gap of only 0.23 on their speaking ability. If the result of the statistic calculation is higher than the $\mathrm{p}$ - value 0.05 , it means there is no significant difference between the two groups. Since the result was 0,903 , there was no significant difference between the groups.

The $t$-value also showed there was no difference between both classes. The t-value was 0,122 and close to 0 . As the p-value and t-value of the pre-test were 0,903 and 0,122 respectively, it could be concluded that there were no significant differences between the two classes in their speaking ability.

The following charts show a more detailed result of students from the tests carried out. The indicators used for scoring are taken from the P2RST. They are content development, pronunciation, performance, coherence, and vocabulary. In the test the students were given a topic they were familiar with and asked to speak for 2-3 minutes. 


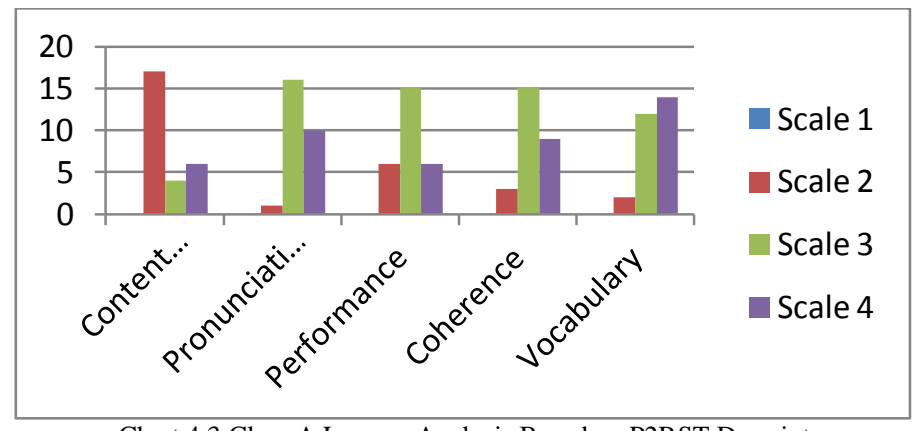

Chart 4.3 Class A Learner Analysis Based on P2RST Descriptors

It could be seen from the test result that none of the students was on scale 1. Class A consisted of 27 students and more than a half of them struggled on the content development. They were familiar with the topic because they had learned about it or had encountered it somewhere but they were still unable to elaborate it. The number of students encountered difficulty was one in pronunciation, two in vocabulary, three in coherence and six in performance. The rest of the student did not have problems in the indicators listed and had great vocabulary range.

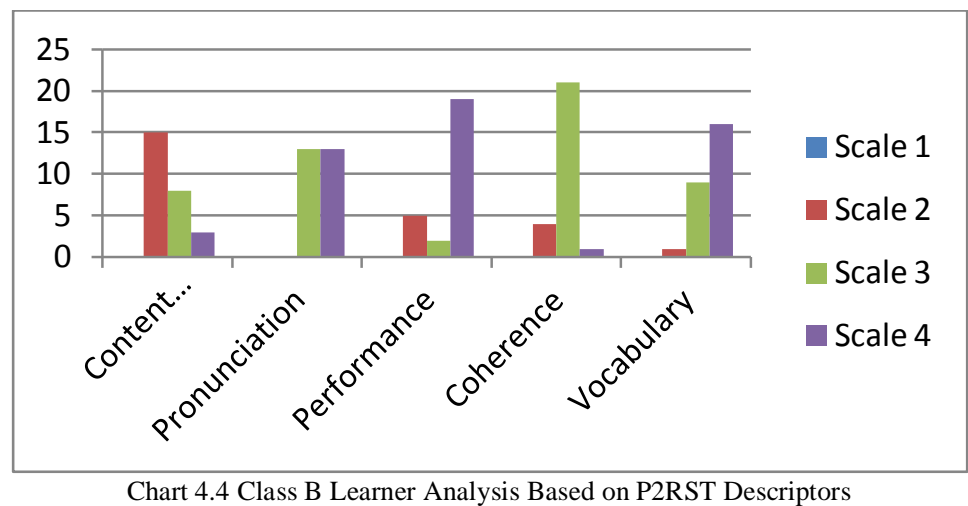

Class B contained 26 students. In this class the students had the same problem as those of the class A in content development as more than half them was on scale 2. Unlike class A, this class did not have a problem at all in pronunciation. The number of students at scale 3 and 4 were similar. Five students had problem in performance, four in coherence, and only one in vocabulary. While it was not necessarily a problem, there was only one student with great coherence. In the previous class there were 9 students who had great coherence. However, this class was superior in terms of performance compared to class A students. The design should be made in order for all students able to not only develop on their weakness but also strengthen their already acquired skill. Since both classes had problems with content development and performance, the design was more focused on these skills.

\section{Design of Instruction}

\section{Goal and Objectives of Design}

In the design, the goal and objective are very important to ensure first-year undergraduate students are able to develop their speaking skill. Below is the table detailing the goal and objectives of the instructional design based on the analysis result and in reference to the P2RST rubric.

TABLE 4.5

INSTRUCTIONAL GOAL AND OBJECTIVES

\begin{tabular}{|l|l|}
\hline Instructional Goal & Students are able to develop their speaking skill. \\
\hline \multirow{4}{*}{ Instructional Objectives } & Students are able to expand their knowledge to respond to various topics. \\
\cline { 2 - 2 } & Students are able to pronounce sentences correctly. \\
\cline { 2 - 2 } & Students are able to retain and retrieve vocabularies learned in conversations. \\
\cline { 2 - 2 } & Students are able to speak in sequence and on topic. \\
\cline { 2 - 2 } & Students are able to speak confidently and fluently. \\
\hline
\end{tabular}

For the first year of undergraduate study in Universitas Bandar Lampung, the students learn an upgraded version of topics they have already learned in their previous education. For example, they will learn again how to introduce themselves by speaking their complete biography. They will talk about their big extended family instead of their small family. They will learn how to describe things and persons in details instead of in a few sentences, etc.

\section{Choosing Environment}

Due to time constraint in speaking class where students learned 90 minutes per meeting in big class, LMS learning is chosen as an embedded content to facilitate student learning outside classroom situation. LMS Schoology which can be 
assessed from www.schoology.com is considered because of its similar setting as Facebook. This makes the students more familiar in navigating the site (Maning et.al., 2011). The Schoology has three main features; Courses, Groups, and Resources. 'Courses' is a place for students to learn. 'Groups' is a place for the student to interact with each other and 'Recourses' is a place where the content of the lesson is compiled. Using Schoology LMS is hoped to expand their knowledge about the topic. In the end, the student will be able to speak in various topics and connect the knowledge with related topics easily.

Besides using Schoology to facilitate learning, the students will also learn outside the classroom (place-based learning) by performing their speaking in real life situation. For example, when they learn how to describe a place, the student will go to the place and record a video of the place. They will talk about their chosen place throughout the video based on the length of video instructed in the task. Similarly, when they are tasked to give direction to someone, they could do role play with their friend or partner of the task. Then, they can ask someone to record their interactions. This activity will also boost their performance skill which is one of the big problems in both classes. Both Schoology and place-based learning allow the students to cooperate and make inquiries to their friends and teacher online which reflect contextual learning.

\section{Designing Activity}

The activity will be designed in Schoology Resource feature. The content of the lesson is planned to elicit students to speak more. Since the students have difficulties in expanding their topics in speaking thus making them perform poorly, the activities will emphasize heavily on speaking in various common topics before moving forward to weightier topics like political issues or educational trends.

In the classroom, students will learn by answering inquiries from the teacher, learning in groups with their friends and having a role play about the topic learned. Outside, they will learn from LMS Schoology to expand their knowledge about the topic they learned. The classroom activity emphasizes the speaking practice while the activity in Schoology will focus on how to make the student absorb information and retain it for a long time. After learning a topic, the students are expected to make a video of their using the topic in real life situation.

\section{Developing Instructional Design}

The design is developed based on the result of the pilot unit. Depending on its success, the design will be developed to be similar to the pilot unit or completely different from it. This step will continue until the most suitable design for the student is found.

\section{E. Implementation}

The design is planned to be implemented for the first year of undergraduate study of Teacher Training and English Education of Universitas Bandar Lampung for a semester. Throughout the implementation, there will be formative evaluation. Formative evaluation is a small scale evaluation held to solve small and immediate problems occurred in the implementation process. It is also used to revise any content of study and learning process in order to optimize student learning experience. (Brown and Green, 2016).

\section{F. Evaluation}

After the implementation in the semester, the design will be reviewed using the summative evaluation to know whether the major goal of the study is achieved and the effectiveness of using the design. Below is the illustration of both formative and summative evaluation from from Fizpatrick, Sanders, and Worthen (2004) as cited by Brown and Green (2016) that will be used as guidelines for the evaluation. 


\begin{tabular}{|c|c|c|}
\hline Criterion & Formative Evaluation & Summative Evaluation \\
\hline Purpose & To determine value or quality & To determine value or quality \\
\hline Use & $\begin{array}{l}\text { To improve a program or } \\
\text { instruction }\end{array}$ & $\begin{array}{l}\text { To make decisions about the } \\
\text { instruction's future or adoption }\end{array}$ \\
\hline Audience & Program administrators and staff & $\begin{array}{l}\text { Program administrators and/or potential } \\
\text { consumer or funding agency }\end{array}$ \\
\hline By Whom & $\begin{array}{l}\text { Primarily internal evaluators, } \\
\text { supported by external evaluators }\end{array}$ & $\begin{array}{l}\text { External evaluators, supported by } \\
\text { internal evaluators in unique cases }\end{array}$ \\
\hline Major Characteristics & $\begin{array}{l}\text { Provides feedback so program } \\
\text { personnel can improve it }\end{array}$ & $\begin{array}{l}\text { Provides information to enable program } \\
\text { personnel to decide whether to continue } \\
\text { it, or consumers to adopt it }\end{array}$ \\
\hline Design Constraints & $\begin{array}{l}\text { What information is needed? } \\
\text { When? }\end{array}$ & $\begin{array}{l}\text { What evidence is needed for major } \\
\text { decisions? }\end{array}$ \\
\hline Purpose of Data Collection & Diagnostic & Judgmental \\
\hline Measures & Sometimes Informal & Valid and Reliable \\
\hline Frequency of Data Collection & Frequent & Infrequent \\
\hline Sample Size & Often Small & Usually Large \\
\hline Questions Asked & $\begin{array}{l}\text { What is working? What needs to be } \\
\text { improved? How can it be improved }\end{array}$ & $\begin{array}{l}\text { What results occur? With whom? Under } \\
\text { what conditions? With what cost? }\end{array}$ \\
\hline
\end{tabular}

Based on the table above, formative evaluation is suitable to be held in the implementation step because doing it the value and quality of the design could be known. The feedbacks from this evaluation could be used to improve the design. This evaluation could be done frequently with small samples. Problems in the design will be detected faster so solution could be delivered swiftly in this evaluation. The methods of measurement do not have to be formal so it is easier to carry out. However, in the design of evaluation step, it is recommended to use summative evaluation.

The reason of doing summative evaluation might be the same as that of formative evaluation but, when formative evaluation seeks to improve the design, summative evaluation wants to seek whether the design should be continued or cancelled. The feedbacks in this evaluation mostly came from outside experts ensuring more objective answers. The evaluation is in a large scale with bigger samples. From this evaluation, some problems which could not be seen due to formative evaluation limited sample which might be a major problem for the design could be encountered and started to be addressed. The measurement used in summative evaluation needs to be made as valid and reliable as possible unlike in formative evaluation which adopts flexible measurement. This nature of summative evaluation will minimize the error in the evaluation result.

\section{CONCLUSIONS}

The instructional model of this study is created to develop the first year of undergraduate study students of Teacher Training and English Education Faculty of Universitas Bandar Lampung. The model is designed to counter the weakness of first-year students in content development and performance in the speaking class without leaving out other assessed aspects in the speaking skill. Contextual learning is chosen because it allows the students to not only learn about knowledge in the classroom but also practice the knowledge which makes them able to grasp the lesson better and enable them to retain the knowledge to use in the future. ADDIE model is chosen as the guideline of the model. The result of the previous step in the design will influence how to proceed to the next step. The instructional design has not been tested. It has limited usability (as it is made for developing speaking skill) and scale (it is only in the first year of undergraduate study). Further study to expand the model into a different skill or on a bigger scale is also possible.

\section{ACKNOWLEDGMENTS}

Gratitude is delivered to the Government of Republic of Indonesia through the fund given as a research grant scheme to Universitas Bandar Lampung. The researchers would like to send their gratitude for the financial support for this research. Great thank is also sent to all faculty members in Universitas Bandar Lampung especially those from the Faculty of Teacher Training and Education who have shared great experience and feedback.

\section{REFERENCES}

[1] Asakereh, A., and Dehghannezhad, M. (2015). Student satisfaction with EFL speaking classes: Relating speaking self-efficacy and skills achievement, Issues in Educational Research, 25(4), 345-363.

[2] Baniabdelrahman, A.A. (2013). Effect of Using Internet Tools on Enhancing EFL Students' Speaking Skill, American International Journal of Contemporary Research, 3 (6), 79-87. 
[3] Brown, Abbie H., and Green, Timothy D. (2016). The Essentials of Instructional Design; ConnectingFundamental Principles with Process and Practice, Third Eds., Third Avenue, New York; Routledge.

[4] Bruner, D.A., Sinwongsuwat, K., and Radic-Bojanic, B. (2015). EFL Oral CommunicationTeaching Practices: A Close Look at University Teachers and A2 Students' Perspectives in Thailand and a Critical Eye from Serbia, English Language Teaching, 8 (1), 11-20.

[5] Darmuki, A. (2017). Evaluating Information-processing-based Learning Cooperative Model on Speaking Skill Course. Journal of Language Teaching and Research, Vol. 8, No. 1, pp. 44-51, DOI: http://dx.doi.org/10.17507/jltr.0801.06.

[6] Gagne, Robert M., Wager, Walter W., Golas, Katharine C. and Keller, John M. (2004). Principles of Instructional Design, Fifth Eds.,Davis Drive, Belmont; Wadsworth/Thompson.

[7] Hudson, Clemente C., and Whisler, Vesta R. (2008). Contextual Teaching and Learning for Practitioners, Systemics, Cybernetics and Informatics, 6 (4), 54-58.

[8] Kementrian Pendidikan dan Kebudayaan. (2014). Konsep dan Implementasi Kurikulum 2013. Retrieved from https://kemdikbud.go.id/kemdikbud/dokumen/Paparan/Paparan\%20Wamendik.pdf on $21^{\text {st }}$ October 2018.

[9] Khaefiatunnisa. (2015). The Effectiveness of Contextual Teaching and Learning in Improving Students' Reading Skill in Procedural Text (A Quasi-Experimental Study of the Second Grade Students at One Vocational School in Bandung), Journal of English and Education 2015, 3(1), 80-95.

[10] Latifa, A., Rahman, A., Hamra, A., Jabu, B., and Nur, R. (2015). Developing a Practical Rating Rubric of Speaking Test for University Students of English in Parepare, Indonesia, English Language Teaching, 8 (6), 166-177.

[11] Manning, C., Brooks, W., Crotteau, V., Deidrich, A., Moser, J., and Zwiefelhofer, A. (2011). Tech Tools for Teachers, By Teachers: Bridging Teachers and Students, Wisconsin English Journal, 53 (1), 24-28.

[12] Oradee, T. (2012). Developing Speaking Skills Using Three Communicative Activities (Discussion, Problem-Solving, and Role-Playing), International Journal of Social Science and Humanity, 2(6), 533-535.

[13] Richard, J.C. (2008). Teaching Listening and Speaking From Theory to Practice, New York, NY: Cambridge University Press.

[14] Sakale, R. (2012). Rethinking Speaking Skill in EFL (English Foreign Language) Setting, Sino-US English Teaching, 9 (4), 1100-1111.

[15] Satriani, I., Emilia, E., and Gunawan, M.H. (2012). Contextual Teaching and Learning Approach to Teaching Writing, Indonesian Journal of Applied Linguistics, 2 (1), 10-22.

[16] Schunk, Dale.H. (2012). Learning Theories; An Educational Perspective, Six Eds., Boylston Street, Boston: Pearson.

[17] Surdin. (2018). The Effect of Contextual Teaching and Learning (CTL) Models on learning outcomes of Social Sciences of the material of forms the face of the earth onClass VII of Junior High School, International Journal of Education and Research, 6 (3), 57-64.

[18] Wiseman, C.S. (2012). A Comparison of the Performance of Analytic vs. Holistic Scoring Rubrics to Assess L2 Writing, Iranian Journal of Language Testing, 2 (1), 59-92.

Harpain is a lecturer of English Language Study Program at Bandar Lampung University, Lampung Province, Indonesia. His research interests are language teaching methods and teaching English as a foreign language.

Dameria Magdalena Sidabalok is a lecturer of English Language Study program at Bandar Lampung University, Lampung Province, Indonesia. Her research interests are Teaching English to Young Learners, English language assessment and language teaching methods.

Margaretha Audrey S.C. is an alumnus of Teacher Training and English Education Faculty of Universitas Bandar Lampung. She is going to pursue a master degree in University of Arkansas focusing on Curriculum and instruction. Her research interests are children education, instructional design and curriculum development.

Yulfriwini is a lecturer at Bandar Lampung University, Lampung Province, Indonesia. Her research interest is contextual learning. 